$T$ $\mathrm{HE}$ addition of columbium as ferrocolumbium to high alloy steels is considered to be a relatively critical operation. In the first place, ferrocolumbium dissolves rather slowly in steel, even though it is normally added as particles of $1 / 2$-in. diam or less. Also, because ferrocolumbium has a greater density than many alloys, the particles sink to the bottom of the furnace ladle. Secondly, ferrocolumbium oxidizes readily when in contact with an oxidizing slag, or when exposed to air at elevated temperatures. As a result, the actual recovery of columbium in making Type-347 stainless steel ranges from 70 to 85 pet.

In electric furnace steelmaking, ferrocolumbium is generally added to the furnace through a suitable refining slag. This is done some $30 \mathrm{~min}$ prior to tapping in order to allow time for the alloy to dissolve completely in the bath. During this period, it is vital to stir the bath vigorously in order to achieve an adequate recovery of columbium.

Some steelmakers add part of the ferrocolumbium to the furnace and part to the ladle. Another method is to add all the alloy in the ladle. In all but the latter case, additional furnace time is required, and, presumably, a somewhat higher temperature is needed to insure solution of the alloy.

These inconveniences and disadvantages suggest the use of exothermic ferrocolumbium in the making of columbium-bearing steels.

\section{Laboratory work}

After preliminary work with various exothermic mixes, it appeared to metallurgists of the Vanadium Corp. of America (VCA) that a sodium nitrateferrosilicon type might perform satisfactorily. The manufacture of such a mixture involves crushing ferrocolumbium to a screen size of -8 mesh, mixing sodium nitrate to the extent of 10 pct of the mixture weight, and adding 5 pct ferrosilicon ( 75 pct $\mathrm{Si}$ ) of -200 mesh size. An organic binder is also added to insure close association of the ingredients. The mixture is packed in steel cans-small ones for induction-furnace melts and larger ones for arc-furnace heats.

The mixture was given preliminary evaluation at the VCA Research Center by adding it to a number of heats of Type-347 stainless steel. The first trials were run with $300-1 b$ induction-furnace heats. These were made by melting Armco iron, electrolytic nickel, and low-carbon ferrochrome, to which electrolytic manganese and ferrosilicon were added. Final deoxidation consisted of adding 0.10 pet Al to the bath. Just before tapping, a sample was taken for chemical analysis. The exothermic mixture, packed in one small metal can containing columbium equivalent to an 0.80 pct addition, was placed in a heated ladle, and molten metal was tapped onto it. A hot, vigorous reaction took place, which was

T. W. MERRILL is a metallurgical engineer with the Vanadium Corp. of America. completed before the tap was finished. The temperature of the metal at tap was $2950^{\circ} \mathrm{F}$. Several small ingots were poured and later drilled for chemical analysis.

For a further evaluation of the exothermic mixture, a $3000-1 b$ arc-furnace heat of Type-347 stainless steel was produced. Plate scrap, electrolytic nickel, and low-carbon ferrochrome were melted, and the heat was deoxidized with ferrosilicon and 0.10 pct $\mathrm{Al}$. The original calcium-silicate slag was not replaced. For the 0.80 pct $\mathrm{Cb}$ addition, a single can of exothermic ferrocolumbium mixture was dropped into the ladle just as the heat started to tap. The tapping temperature was regulated to compare with that of a commercial heat. The reaction of the exothermic alloy was not considered to have been any more violent than that experienced when adding exothermic ferrochromium under similar conditions. The heat was poured into $12 \times 12$-in. castiron molds which, when cooled, were drilled for analytical samples.

\section{Test results}

Analyses of the various heats showed that the columbium recovery from the exothermic mixture was above 90 pct; the small heats showed 97 pct recovery or better, and the arc-furnace heat 92.5 pct. Table I shows the average composition of five $300-1 b$ induction heats and the one 3000-1b arc furnace, as well as the columbium recoveries achieved.

\section{Savings shown}

The use of exothermic ferrocolumbium as a ladle addition makes it possible to eliminate the furnace time required when using regular ferrocolumbium. In addition, this alloy mixture permits the steelmaker to take advantage of any residual columbium that may be present in the bath, thus reducing the possibility of off-analysis heats.

Savings per ton will vary, of course, with the individual case. But a typical 10 pct increase in recovery of columbium results in savings as high as $\$ 7$ per ingot ton.

Table I. Test Results of Exothermic Ferrocolumbium Additions to Five 300-lb Induction Heats and One 3000-lb Arc-Furnace Heat

\begin{tabular}{|c|c|c|c|c|c|c|c|}
\hline \multicolumn{8}{|c|}{ Composition, Pet } \\
\hline & $\mathbf{C}$ & $\mathbf{M n}$ & Si & $\mathbf{C r}$ & Ni & $\mathbf{C b}$ & $\mathbf{T a}$ \\
\hline \multirow{4}{*}{$\begin{array}{l}\text { Aim } \\
\text { Induction, Avg } \\
\text { Five Heats } \\
\text { Arc Heat }\end{array}$} & $\begin{array}{l}0.08 \\
0.09\end{array}$ & $\begin{array}{l}1.50 \\
1.38\end{array}$ & $\begin{array}{l}0.50 \\
0.54\end{array}$ & $\begin{array}{l}18.00 \\
18.30\end{array}$ & $\begin{array}{l}9.00 \\
9.07\end{array}$ & $\begin{array}{l}0.80 \\
0.78\end{array}$ & $0 . \overline{02}$ \\
\hline & 0.19 & - & 一 & 15.88 & 8.17 & 0.74 & 0.006 \\
\hline & \multicolumn{5}{|c|}{ Columbium Recovery } & & \\
\hline & \multicolumn{3}{|c|}{ Cb Added, Lb } & \multicolumn{2}{|c|}{$\begin{array}{l}\text { Cb Recov- } \\
\text { ered, Lb }\end{array}$} & \multicolumn{2}{|c|}{$\begin{array}{l}\text { Cb Recov- } \\
\text { ered, Pct }\end{array}$} \\
\hline \multirow{2}{*}{$\begin{array}{l}\text { Induction, Avg } \\
\text { Five Heats } \\
\text { Arc Heat }\end{array}$} & \multicolumn{3}{|c|}{2.40} & \multicolumn{2}{|c|}{2.34} & \multicolumn{2}{|c|}{97.4} \\
\hline & \multicolumn{3}{|c|}{24.00} & \multicolumn{2}{|c|}{22.20} & \multicolumn{2}{|c|}{92.5} \\
\hline
\end{tabular}

